\title{
УДОСКОНАЛЕННЯ ШВИДКІСНО-СИЛОВИХ ЯКОСТЕЙ СПРИНТЕРІВ НА ЕТАПІ ПОЧАТКОВОЇ ПІДГОТОВКИ
}

\author{
Оксана Саволайнен ${ }^{1}$, Валерій Кузнецов ${ }^{2}$, Олександр Валькевич ${ }^{3}$, \\ Роман Черкашин ${ }^{3}$, Надія Карабанова ${ }^{3}$ \\ ${ }^{1}$ Національний університет фізичного виховання і спорту України, Київ, Україна. \\ ${ }^{2}$ Київський національний економічний університет імені Вадима Гетьмана, Київ, Україна. \\ ${ }^{3}$ Східноєвропейський національний університет імені Лесі Українки, Луцьк, Україна, \\ sashavalkevich26@gmail.com
}

https://doi.org/10.29038/2220-7481-2019-04-117-123

\begin{abstract}
Анотації
Актуальність дослідження. У статті розглянуто роботу в дитячо-юнацьких спортивних школах на етапах початкової підготовки, які відрізняються великим розмаїттям засобів і методів тренування, які вимагають від юних спортсменів прояву організованості, ініціативи, що сприяє вдосконаленню всіх фізичних якостей та вихованню організаційних навичок і працелюбності дітей. Здійснюване в тісному зв'язку з розумовим, моральним, естетичним вихованням та трудовим навчанням фізичне виховання й спорт, зокрема, сприяють усебічному розвитку юних спортсменів. Підвищення ефективності підготовки юних спортсменів - найбільш гостра проблема школи спорту. Роботу багатьох спортивних шкіл характеризують утрати спортивних дарувань, а також незацікавленість дітей у спорті. Традиційними стали роз'єднаність загальноосвітніх і спортивних шкіл у виконанні завдань масового юнацького спорту, недостатня відповідність організаційних форм підготовки досягненням сучасної методики. Мета дослідження - розробити й експериментально обгрунтувати програму розвитку швидкісно-силових якостей легкоатлетів на етапі початкової підготовки. Завдання дослідження визначення рівня розвитку швидкісно-силових якостей спортсменів на етапі початкової підготовки, розробка програми розвитку швидкісно-силових якостей спринтерів, перевірка ефективності цієї програми. Методи дослідження - аналіз науково-методичної літератури, педагогічне спостереження, педагогічне тестування, педагогічний експеримент, методи математичної статистики. Результати дослідження. Результати проведених досліджень засвідчують, що під впливом розробленої технології показники швидкісно-силових якостей юних спортсменів вірогідно покращились: із бігу на 30 м із низького старту - на 6,63 \%, із бігу на 30 м із ходу - на 7,09 \%, із бігу 300 м - на $1,27 \%$, стрибка в довжину з місця - на 4,21\% та кидка ядра двома руками - на 41,4 \%. Результати проведеного педагогічного експерименту свідчать про те, що навчально-тренувальний процес спортсменів на етапі початкової підготовки має свою специфіку, зумовлену їхніми анатомофізіологічними і психологічними особливостями, а також пристосуванням до нових умов, які виникають у результаті поєднання тренування з навчанням у школі. Тому існує необхідність пошуків нових прийомів та методів тренування, що враховували б виявлені особливості.
\end{abstract}

Ключові слова: контроль, навантаження, тренувальний процес, фізичний стан, швидкісні якості, силова підготовленість.

Оксана Саволайнен, Валерий Кузнецов, Александр Валькевич, Роман Черкашын, Надежда Карабанова. Совершенствование скоростно-силовых качеств спринтеров этапе начальной подготовки. Актуальность исследования. В статье рассматривается работа в детско-юношеских спортивных школах на этапах начальной подготовки, которые отличаются большим разнообразием средств и методов тренировки, которые требуют от юных спортсменов проявления организованности, инициативы, способствует совершенствованию всех физических качеств и воспитанию организационных навыков и трудолюбия детей. Осуществляемое в тесной связи с умственным, нравственным, эстетическим воспитанием и трудовым обучением физическое воспитание и спорт, в частности, способствует всестороннему развитию юных спортсменов. Повышение эффективности подготовки юных спортсменов - наиболее острая проблема школы спорта. Работу многих спортивных школ характеризует потери спортивных дарований, а также незаинтересованность детей в спорте. Традиционными стали разобщенность общеобразовательных и спортивных школ в решении задач массового юношеского спорта, недостаточное соответствие организационных форм подготовки достижением современной методики. Цель исследования - определение уровня развития скоростно-силовых качеств спортсменов на этапе начальной подготовки, разработка программы развития скоростно-силовых качеств спринтеров, проверка эффективности данной программы. Задача исследования - определение уровня развития скоросно-силовых качеств спортсменов на этапе начальной подготовки, разработка программы развития скоростно-силовых качеств спринтеров, проверка эффективности данной программы. Методы исследования - 
анализ научно-методической литературы, педагогическое наблюдение, педагогическое тестирование, педагогический эксперимент, методы математической статистики. Результаты исследования. Результаты проведенных исследований свидетельствуют, что под влиянием разработанной технологии показатели скоростно-силовых качеств юных спортсменов достоверно улучшились: в беге на 30 м с низкого старта - на 6,63 \%, в беге на 30 м с ходу - на 7,09\%, в беге 300 м - на 1,27\%, прыжка в длину с места - на 4,21 \% и броска ядра двумя руками - на 41,4 \%. Результаты проведенного педагогического эксперимента свидетельствуют о том, что учебно-тренировочный процесс спортсменов на этапе начальной подготовки имеет свою специфику, обусловленную их анатомо-физиологическими и психологическими особенностями, а также приспособлением к новым условиям, которые возникают в результате сочетания тренировки с учебой в школе. Поэтому есть необходимость в поисках новых приемов и методов тренировки, учитывающих выявленные особенности.

Ключевые слова: контроль, нагрузки, тренировочный процесс, физическое состояние, скоростные качества, силовая подготовленность.

Oksana Savolainen, Valerii Kuznetsov, Oleksandr Valkevych, Roman Cherkashyn, Nadiia Karabanova. Improvement of Speed and Power Qualities of Sprinters at the Stage of Initial Training. Relevance of Research. The research paper deals with work at children's and youth sports schools at the stages of initial training, which are characterized by a great variety of means and methods of training, which require the organization of young sportsmen, an initiative that promotes the improvement of all physical qualities and the upbringing of organizational skills and hard work of children. Physical education and sports, in particular, contribute to the comprehensive development of young athletes, in close connection with mental, moral, aesthetic and labor education. Increasing the effectiveness of training young athletes is the most acute problem of sports school. The work of many sports schools is characterized by the loss of sports talents, as well as the lack of interest of children in sports. Dissociation of general and sports schools in solving the problems of mass youth sports, lack of conformity of organizational forms of preparation by the achievements of modern methods became a traditional trend. The Purpose of the Research is to develop and experimentally substantiate the program of development of speed and power qualities of athletes at the stage of initial training. The Tasks of the Study consisted in determining the level of development of speed and power qualities of athletes at the stage of initial training, development of the program of development of speed and power qualities of sprinters, verification of the effectiveness of this program. Research Methods are analysis of scientific and methodological literature, pedagogical observation, pedagogical testing, pedagogical experiment, methods of mathematical statistics. Results of the Research. The results of the conducted researches show that under the influence of the developed technology indicators of speed and power qualities of young athletes have probably improved at: $30 \mathrm{~m}$ sprint from a low start - by $6.63 \%, 30 \mathrm{~m}$ sprint - by 7,09 \%, $300 \mathrm{~m}$ sprint - by 1,27 \%, standing long jump - by $4,21 \%$ and standing throwing by two hands - by $41,4 \%$. The Results of the pedagogical experiment show that the training process of athletes at the stage of initial training has its own specificity, due to their anatomical and physiological and psychological characteristics, as well as adaptation to the new conditions that appear from the combination of training with study at school. Therefore, there is a need to look for new techniques and training methods that take into account the identified features.

Key words: control, loading, training process, physical condition, speed qualities, training.

Вступ. Основні спрямування реформ загальноосвітньої й професійної школи вказують на необхідність прийняття дієвих заходів для забезпечення в підростаючого покоління міцного здоров'я та різностороннього фізичного розвитку, покращення якості підготовки резервів для спорту вищих досягнень.

Підвищення ефективності підготовки юних спортсменів - найбільш гостра проблема школи спорту. Роботу багатьох спортивних шкіл характеризують утрати спортивних дарувань, а також незацікавленість дітей у спорті. Традиційними стали роз'єднаність загальноосвітніх і спортивних шкіл у виконанні завдань масового юнацького спорту, недостатня відповідність організаційних форм підготовки досягненням сучасної методики [2].

Важливу роль відіграє обгрунтування теоретико-методичних положень такої підготовки, яка забезпечить гармонійний розвиток дітей та одночасно закладе фундамент для досягнення вершин спортивної майстерності [5].

Фізичне виховання дітей $\epsilon$ невід’ємною частиною всієї навчально-тренувальної роботи спортивної школи й займає важливе місце в підготовці підростаючого покоління до життя та суспільно корисної праці.

Природний розвиток систем організму дітей має чітко виражені послідовність і циклічність: етапи прискореного росту періодично змінюються фазами вповільненого розвитку. Оскільки періоди прискореного вікового розвитку (так звані сенситивні періоди) рухової функції характеризуються підвищеними адаптаційними можливостями організму до дій, доцільно під час тренувальних занять робити більші акценти саме на розвиток пріоритетних у певні періоди рухових якостей [1]. 
Мета дослідження - розробити й експериментально обгрунтувати технологію розвитку швидкісно-силових якостей легкоатлетів на етапі початкової підготовки.

Завдання дослідження - визначення рівня розвитку швидкісно-силових якостей спортсменів на етапі початкової підготовки, розробка програми розвитку швидкісно-силових якостей спринтерів, перевірка ефективності цієї програми.

Матеріал і методи дослідження включали теоретичний аналіз й узагальнення науково-методичної літератури, бесіди з фахівцями, педагогічне спостереження, педагогічний експеримент, методи математичної статистики.

Для визначення рівня розвитку швидкісно-силових якостей спринтерів на етапі початкової підготовки та визначення ефективності запропонованої програми на початку й у кінці експерименту використано такі тестові вправи, як біг на 30 м із низького старту, біг на 30 м із ходу, біг на 300 м, стрибок у довжину з місця, кидок ядра (3 кг) знизу-вперед двома руками.

Вибираючи тестові вправи, ми припускали, що вони об'єктивно оцінювати рівень розвитку швидкісно-силових якостей спринтерів на етапі початкової підготовки. Крім того, ці вправи відповідали вимогам програми для спеціалізованих навчально-спортивних установ.

Дослідження проводили в період із вересня 2017 р. по грудень 2018 р. У ньому взяло участь легкоатлети групи початкової підготовки другого року навчання в кількості 24 осіб. Відповідно до мети дослідження й для виконання поставленого завдання сформовано експериментальну $(\mathrm{E}, \mathrm{n}=12)$ та контрольну групи (КГ, n=12), до якої ввійшли юні легкоатлети ДЮСШ №1 м. Ківерці та ДЮСШ Луцького району, котрі займалися в групі з легкої атлетики (біг на короткі дистанції). Від усіх учасників отримано письмову згоду на участь у нашому дослідженні. Дослідження проводили на базі Східноєвропейського національного університету імені Лесі Українки.

Виклад основного матеріалу й обгрунтування отриманих результатів дослідження. Педагогічне дослідження проходило в чотири етапи.

На першому етапі (вересень 2017 р.) проводився аналіз літературних джерел, вивчення практичного досвіду застосування засобів у процесі навчання. Здійснювалася розробка загальної концепції дослідження, визначалися його завдання встановлювалися конкретні методи дослідження для виконання поставлених завдань. Визначено експериментальну базу, підібрано контингент обстежуваних. Крім того, вивчено комплекси тестів для оцінки швидкісно-силових якостей, а також розроблено експериментальну програму тренування.

Зокрема, за програмою осінньо-зимовий мезоцикл розділено на загальнопідготовчий (шість тижнів), спеціальнопідготовчий (п'ять тижнів) та змагальний (три тижні) періоди. Головним завданням загальнопідготовчого етапу створення фундаменту для наступного збільшення тренувальних навантажень. При цьому заняття разом із вправами на ЗФП включали прискорення (5-6 разів по 40 м) на техніку. Виконувалося багато роботи швидкісно-силового характеру: стрибкові вправи, вправи з бар'єрами, із набивними м'ячами та ін. Вправи проводили за допомогою таких методів тренування, як повторний, перемінний, колового тренування та змагальний. Тренувальні заняття здійснювали чотири рази на тиждень по 90 хв. Зранку спортсмени виконували ранкову гімнастику.

Завданням спеціальнопідготовчого періоду було вдосконалення техніки бігу та підвищення швидкості рухів.

I-й тиждень. Біг три рази X 60 м - дві серії. Швидкість бігу - 50 \% від максимально можливої. Тривалість відпочинку між серіями - 3-5 хв. II-й тиждень. Довжина дистанції зменшується, швидкість збільшується на $75 \%$. Біг - три рази X 50 м - дві серії. Тривалість відпочинку між серіями - 3-6 хв, залежно від відновлення спортсмена. III-й тиждень. Біг зі зміною ритму - три рази X 60 м - дві серії. Відстань 60 м пробігається таким чином: 25 м - швидко, 10 м - вільного бігу, 25 м - швидко. Швидкість - 75 \%. Тривалість відпочинку між серіями 2-4 хв. $I V$-й тиждень. Швидкість бігу збільшується до максимальної, два рази X 30 м - дві серії. Тривалість відпочинку між серіями - 3-4 хв. V-й тиждень. Те саме, що й на III-му тижні, швидкість збільшується до максимальної, кількість повторень зменшується, біг - два рази X 60 м - дві серії. Тривалість відпочинку між серіями - 2-4 хв.

Другий мезоцикл також розділений на два періоди - загальнопідготовчий (шість тижнів) та спеціальнопідготовчий (чотири тижні).

Метою загальнопідготовчого періоду було вдосконалення бази 3 поступовим підвищенням навантаження для всіх м'язів тіла, приділення більшої уваги техніці бігу, відбувався плавний перехід до спеціальнопідготовчого періоду, у якому, відповідно, збільшувались обсяг та інтенсивність тренувальних навантажень. 
Під час змагального періоду загальний обсяг тренувальних навантажень знижується, а його інтенсивність збільшується. Достатньо одного дня в тиждень інтенсивної роботи, а відпочинок перед змаганнями триває 1-2 дні. Змагальний період - 3-4 тижні, у цей період відбувається підвищення спортивної форми й усунення окремих недоліків.

Після змагального етапу настає перехідний етап, який триває 2-4 тижні. У цей період відбувається активний відпочинок у спортивному таборі, для підтримання спортивної форми спортсменів.

Контрольна група займалася за такою самою структурою річного макроциклу. Тренування здійснювалося за програмою.

На другому етапі педагогічного дослідження (жовтень - листопад 2017 р.) проводилися попередні тестування швидкісно-силових якостей юних легкоатлетів. Для цього використовували тести, які широко представлені в навчально-методичній літературі. Виміри здійснювали після обов'язкової розминки. Перед кожним тестом зі спортсменами проводили інструктаж про зміст і правильність виконання завдання. Усього обстежено 24 особи.

Третій етап (лютий 2018 р. - травень 2018 р.) стосувався проведення основного педагогічного експерименту. Результати попереднього, констатувального, експерименту засвідчили відсутність вірогідних відмінностей у розвитку швидкісно-силових якостей серед юних легкоатлетів. Як в експериментальній, так і в контрольній групах участь у дослідженнях брала однакова кількість дітей - по 12 осіб. Основною відмінністю навчально-тренувального процесу в групах було те, що за використання одних і тих самих засобів розвитку швідкісно-силових здібностей використовували різноманітні методи тренування. Такими методами в експериментальній групі були повторний, перемінний, змагальний $\mathrm{i}$ колового тренування, а в контрольній групі використовували повторний та змагальний методи.

На четвертому етапі (червень - грудень 2018 р.) здійснено обрахунок отриманих результатів, узагальнено результати дослідження, сформовано висновки щодо результатів проведеного дослідження. Здійснювалось оформлення тексту дипломної роботи; розроблено практичні рекомендації, які грунтуються на висновках нашої роботи.

Результати проведеного констатувального експерименту з визначення швидкісно-силових якостей легкоатлетів різної статі, котрі займаються в ДЮСШ у групі початкової підготовки другого року навчання, представлені в табл 1.

Таблиия 1

Показники швидкісно-силових якостей легкоатлетів 11-12 років різної статі

\begin{tabular}{|c|c|c|c|c|}
\hline \multirow[t]{2}{*}{ № 3/II } & \multirow[t]{2}{*}{ Тести } & $\begin{array}{c}\mathrm{E} \Gamma \\
\mathrm{n}=12\end{array}$ & $\begin{array}{c}\mathrm{K} \Gamma \\
\mathrm{n}=12\end{array}$ & \multirow[t]{2}{*}{$\mathbf{t}(\mathbf{p})$} \\
\hline & & $\bar{x} \pm S$ & $\bar{x} \pm S$ & \\
\hline 1 & Біг 30 м з низького старту, $c$ & $4,76 \pm 0,44$ & $4,64 \pm 0,26$ & $\begin{array}{c}0,01 \\
p>0,05\end{array}$ \\
\hline 2 & Біг 30 м із ходу, $c$ & $4,46 \pm 0,34$ & $4,34 \pm 0,26$ & $\begin{array}{c}0,01 \\
p>0,05\end{array}$ \\
\hline 3 & Біг $300 \mathrm{M}, c$ & $60,82 \pm 4,18$ & $58,34 \pm 4,16$ & $\begin{array}{c}0,22 \\
\mathrm{p}>0,05\end{array}$ \\
\hline 4 & Стрибок у довжину з місця, $c$ м & $179,21 \pm 4,21$ & $179,67 \pm 5,33$ & $\begin{array}{c}0,04 \\
\mathrm{p}>0,05\end{array}$ \\
\hline 5 & $\begin{array}{l}\text { Кидок ядра двома руками } \\
\text { знизу-вперед, } м\end{array}$ & $5,41 \pm 2,09$ & $5,69 \pm 1,81$ & $\begin{array}{c}0,02 \\
p>0,05\end{array}$ \\
\hline
\end{tabular}

Середні величини досліджуваних показників швидкісно-силових якостей не мали вірогідних відмінностей серед експериментальної та контрольної груп, які брали участь у контрольних випробуваннях.

Навчальна програма для дитячо-юнацьких спортивних шкіл - документ, який регламентує організацію та проведення навчально-тренувальної роботи спортивних шкіл.

Отримавши результати дослідження, ми мали змогу порівняти їх із контрольно-перевідними рівнями.

За вісім місяців показники спортсменів експериментальної групи мали значні позитивні зміни. Це викликано таким:

- тренування проводили за допомогою методів тренування (повторний, перемінний, метод колового тренування та змагальний); 
- під час прискорень акцентовано на техніці бігу, пульсі спортсменів відповідно до змісту вправи та відсоткового співвідношення виконання вправи відносно максимальної швидкості бігу;

- спортсмени виконували ранкову зарядку.

Табличя 2

Динаміка досліджувальних показників під впливом програми з удосконалення швидкісно-силових здібностей юних легкоатлетів

\begin{tabular}{|c|c|c|c|c|}
\hline \multirow{3}{*}{ Етапи дослідження } & \multicolumn{4}{|c|}{ Досліджувані групи } \\
\hline & \multicolumn{2}{|c|}{ експериментальна група (12 осіб) } & \multicolumn{2}{|c|}{ контрольна група (12 осіб) } \\
\hline & $\bar{x} \pm S$ & $\mathbf{t}(\mathbf{p})$ & $\bar{x} \pm S$ & $\mathbf{t}(\mathbf{p})$ \\
\hline \multicolumn{5}{|c|}{$\begin{array}{r}\text { Динаміка результатів юних легкоатлетів із бігу на } 30 \text { м низького старту під впливом тренувань } \\
\text { iз застосуванням авторської програми }\end{array}$} \\
\hline Початковий & $4,76 \pm 0,05$ & \multirow{2}{*}{$\begin{aligned} & 3,14 \\
\mathrm{p} & <0,05\end{aligned}$} & $4,64 \pm 0,06$ & \multirow{2}{*}{$\begin{aligned} 1,65 \\
\mathrm{p}>0,05\end{aligned}$} \\
\hline Кінцевий & $4,47 \pm 0,05$ & & $4,60 \pm 0,06$ & \\
\hline \multicolumn{5}{|c|}{$\begin{array}{l}\text { Динаміка результатів юних легкоатлетів із бігу на } 30 \text { м із ходу під впливом тренувань } \\
\text { із застосуванням авторської програми }\end{array}$} \\
\hline Початковий & $4,76 \pm 0,44$ & \multirow{2}{*}{$\begin{aligned} & 4,13 \\
\mathrm{p} & <0,05\end{aligned}$} & $4,64 \pm 0,26$ & \multirow{2}{*}{$\begin{array}{c}1,52 \\
\mathrm{p}>0,05\end{array}$} \\
\hline Кінцевий & $4,50 \pm 0,05$ & & $4,51 \pm 0,06$ & \\
\hline \multicolumn{5}{|c|}{$\begin{array}{c}\text { Динаміка результатів юних легкоатлетів із бігу на } 300 \text { м із ходу під впливом тренувань } \\
\text { iз застосуванням авторської програми }\end{array}$} \\
\hline Початковий & $60,82 \pm 4,18$ & \multirow{2}{*}{$\begin{aligned} & 0,62 \\
& \mathrm{p}<0,05\end{aligned}$} & $59,60 \pm 0,80$ & \multirow{2}{*}{$\begin{aligned} 0,16 \\
\mathrm{p}>0,05\end{aligned}$} \\
\hline Кінцевий & $56,08 \pm 0,87$ & & $58,34 \pm 4,16$ & \\
\hline \multicolumn{5}{|c|}{$\begin{array}{c}\text { Динаміка результатів юних легкоатлетів зі стирибків у довжину з місця під впливом тренувань } \\
\text { iз застосуванням авторської програми }\end{array}$} \\
\hline Початковий & $179,21 \pm 4,21$ & \multirow{2}{*}{$\begin{array}{c}6,2 \\
\mathrm{p}<0,05\end{array}$} & $179,67 \pm 5,33$ & \multirow{2}{*}{$\begin{array}{c}7,86 \\
\mathrm{p}<0,05\end{array}$} \\
\hline Кінцевий & $187,08 \pm 1,9$ & & $180,75 \pm 1,3$ & \\
\hline \multicolumn{5}{|c|}{$\begin{array}{c}\text { Динаміка результатів юних легкоатлетів із кидка ядра двома руками знизу-вперед } \\
\text { під впливом тренувань із застосуванням авторської програми }\end{array}$} \\
\hline Початковий & $5,41 \pm 2,09$ & \multirow{2}{*}{$\begin{array}{c}5,52 \\
p<0,05\end{array}$} & $5,69 \pm 1,81$ & \multirow{2}{*}{$\begin{array}{c}1,25 \\
\mathrm{p}>0,05\end{array}$} \\
\hline Кінцевий & $8,39 \pm 0,39$ & & $6,17 \pm 0,35$ & \\
\hline
\end{tabular}

Із бігу на 30 м із ходу результати спортсменів контрольної групи мали такі зміни: від 4,64 $\pm 0,06$ с до

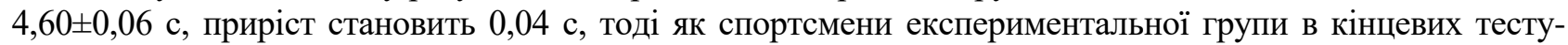

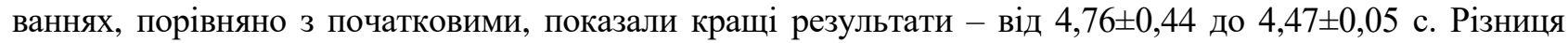
початкових і кінцевих результатів юних легкоатлетів становить 0,29 с. Із бігу на 30 м із ходу результати спортсменів контрольної групи мали такі зміни: від 4,64 \pm 0,26 с до 4.51 $\pm 0,06$ с, різниця дорівнює 0,13 с. Спортсмени експериментальної групи в кінцевих тестуваннях, порівняно 3 початковими, показали

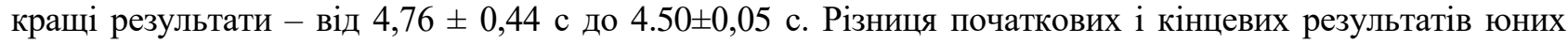
легкоатлетів становить 0,21 с. Показники з бігу на 300 м мали позитивні зрушення. У контрольній групі за вісім місяців результати юних легкоатлетів змінилися від 59,60 \pm 0,80 с до 58,34 \pm 4,16 с, тобто покращилися на 1,26 с. В експериментальній групі спортсмени мали більші зрушення в результатах від $60,82 \pm 4,18$ с до $56,08 \pm 0,87$ с, тобто на 4,74 с.

Зі стрибків у довжину 3 місця спортсмени контрольної групи на початковому етапі показали результат $179,67 \pm 5,33$ см, спортсмени експериментальної групи $-179,21 \pm 4,21$. На кінцевому етапі результати спортсменів мали покращення в контрольній групі до $180,75 \pm 1,38$ см, а в експериментальній

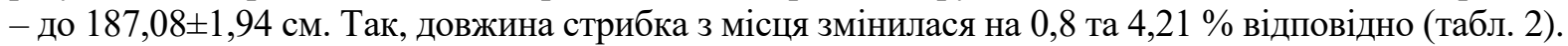

Зміни результатів зі стрибків у довжину (табл. 2) мали достовірні зрушення як в експериментальній групі, $\mathrm{t}=6,2(\mathrm{p}<0,05)$, так і в контрольній, $\mathrm{t}=7,86(\mathrm{p}<0,05)$.

У контрольному тесті кидок ядра двома руками знизу-вперед показники мали такі зрушення: у контрольній групі збільшились на 11,3%, в експериментальній - 52,2 \% (табл. 2).

Юні легкоатлети контрольної групи попередньо мали середній показник 5,54 м, який за вісім місяців мав зрушення до 6,17 м. В експериментальній групі середній показник спортсменів мав 5,51 м на початку, а зріс до 8,39 м - на кінцевому тестуванні. 
За даними, представленими в таблиці, можемо побачити, як на краще змінилися показники швидкісно-силових якостей юних легкоатлетів на етапі початкової підготовки в експериментальній групі. Таке виявилося можливим за допомогою спеціально створених педагогічних умов із раціонального поєднання методів розвитку швидкісної сили в дітей 11-12 років. Крім того, використовуючи різноманітні швидкісно-силові вправи, у юних легкоатлетів значно збільшується руховий арсенал, що в майбутньому може стати надійним фундаментом у подальшому спортивному вдосконаленні.

Дискусія. Аналіз літературних джерел свідчить про те, що швидкісно-силові здібності є провідними в легкій атлетиці, тому їх розвиток має значення на всіх етапах багаторічного тренування. Однак тренери в роботі з юними спортсменами звертають недостатньо уваги на їх удосконалення, особливо на етапі початкової підготовки. Це пов'язано з тим, що методика вдосконалення швидкісно-силових якостей на цьому етапі багаторічної підготовки в спеціальній літературі висвітлена поверхово. Проведене тестування показників швидкісно-силових якостей легкоатлетів груп початкової підготовки на початку річного макроциклу встановило, що розвиток їх приналежності відповідав нижчому від середнього рівню.

За результатами констатувального експерименту розроблено технологію вдосконалення швидкісно-силових якостей юних легкоатлетів, яка передбачала використання таких методів тренування, як повторний, перемінний, колового тренування та змагальний, контроль за ЧСС спортсменів відповідно до змісту вправи, раціональна швидкість пробігання відрізків та щоденне виконання ранкової зарядки.

Тренування юних легкоатлетів контрольної групи за програмою ДЮСШ також сприяли позитивним змінам у показниках швидкісно-силових якостей, але ці зміни виявилися незначними.

Розроблена технологія сприяє значному підвищенню рівня розвитку швидкісно-силових якостей юних легкоатлетів. Особливостями технології розвитку швидкісно-силових якостей легкоатлетів 1112 років у різних періодах річного макроциклу були в загальнопідготовчому періоді в основній частині тренування, коли виконувалися комплекси вправ (із бар'єрами, стрибкові та колового тренування); у спеціальнопідготовчому - в основній частині увагу приділяли біговій роботі (пробігання відрізків); в основній частині тренування змагального періоду роботу спрямовано безпосередньо на виконання змагальних вправ.

Висновки. Упроваджена прогма розвитку швидкісно-силових якостей легкоатлетів 11-12 років в умовах занять у дитячо-юнацькій спортивній школі сприяла покращенню рівня розвитку швидкісносилових здібностей юних спортсменів експериментальної групи. Під впливом розробленої програми показники швидкісно-силових якостей юних спортсменів вірогідно покращились: із бігу на 30 м із низького старту - на 6,63 \%, із бігу на 30 м із ходу - на 7,09 \%, із бігу 300 м - на 1,27 \%, стрибка в довжину $з$ місця - на 4,21 \% та кидка ядра двома руками - на 41,4 \%

Основою технології $є$ проведення тренувань за допомогою таких методів, як повторний, перемінний, колового тренування й змагальний метод. Великий вплив має педагогічний контроль спортсменів під час усього тренувального заняття: техніка виконання вправ, стан спортсмена, правильно побудовані режими навантаження та відпочинку. Досить важливий вплив на організм становить правильна побудова змісту мікроциклу тренування, раціональна швидкість пробігання відрізків та виконання вправ ранкової гімнастики.

\section{Джерела та література}

1. Артюшенко О. Ф., Стеценко А. І. Легка атлетика: навч. посіб. для студентів вищ. навч. закл. Черкаси: Вид. Вовчок О. Ю., 2006. 424 с.

2. Булатова М. М. Теоретико-методические основы реализации функциональных резервов спортсменов в тренировочной и соревновательной деятельности: автореф. дис. ... д-ра пед. наук. Киев: УГУФВС, 2006. $44 \mathrm{c}$.

3. Богачев Е. В., Карягин И. А. Кроссфит. Руководство по тренировкам. Москва: 2013. 142 с.

4. Вендлер Д. Простая и эффективная система тренировок для максимальной силы. Москва, 2008. 75 с.

5. Верхошанский Ю. В. Основы специальной физической подготовки спортсменов. Минск: Физкультура и спорт, 2008 г. 221 с.

6. Легка атлетика: підручник. Житомир: Вид-во ЖДУ ім. І. Франка, 2013. С. 13-18. ISBN 978-966-485060-2

7. Розвиток швидкісно-силових якостей легкоатлетів у групах підвищення: спортивної майстерності: навч.-метод. рек./СНУ ім. Лесі Українки; уклад Черкашин Р. Є, Валькевич О. В. Луцьк, 2018. 50 с.

8. Кокорев Д. А., Выприков Д. В., Везеницин, О. В. Методика использования функционального многоборья в процессе физического воспитания. Теория и практика физ. культуры. 2016. № 9. С. 16-18.

9. Фізична культура. Програма для загальноосвітніх навчальних закладів, 5-9 класів. Київ: 2008. 112 с. 
10. Юшкевич Т. П., Романов И. В. Применение элементов кроссфита в тренировочном процессе десятиборцев 15-16 лет. Мир спорта. 2017. 1(66). С. 17-23.

\section{References}

1. Artiushenko, O. F., Stetsenko, A. I. (2006). Lehka atletyka: Navchalnyi posibnyk dlia studentiv vyshchykh navchalnykh zakladiv. Cherkasy: Vyd. Vovchok O. Iu., 424.

2. Bulatova, M. M. (2006). Teoretiko-metodicheskie osnovy realizacii funkcionalnyh rezervov sportsmenov v trenirovochnoj i sorevnovatelnoj deyatelnosti. (Avtoref. dis. ... d-raped. nauk). Kyiv: UGUFVS, 44.

3. Bogachev, E. V., Karyagin, I. A. (2013). Krossfit. Rukovodstvo po trenirovkam. Moskva, 142.

4. Vendler, D. (2008). Prostaya i effektivnaya sistema trenirovok dlya maksimalnoj sily, Moskva, 75.

5. Verhoshanskij, Yu. V. (2008). Osnovy specialnoj fizicheskoj podgotovki sportsmenov. Minsk: Fizkultura i sport, 221.

6. Lehka atletyka: Pidruchnyk. Zhytomyr: Vydavnytstvo ZhDU im. I. Franka, 2013, 13-18. ISBN 978-966-485060-2

7. Rozvytok shvydkisno-sylovykh yakostei lehkoatletiv u hrupakh pidvyshchennia: sportyvnoi maisternosti: navchalno-metodychni rekomendatsii/SNU im. L. Ukrainky; uklad Cherkashyn, R. Ye, Valkevych, O. V. Lutsk. 2018, 50.

8. Kokorev, D. A., Vyprikov, D. V., Vezenicin, O. V. (2016). Metodika ispolzovaniya funkcionalnogo mnogoborya v processe fizicheskogo vospitaniya. Teoriya i praktika fiz. kultury, № 9, 16-18.

9. Fizychna kultura. Prohrama dlia zahalnoosvitnikh navchalnykh zakladiv, 5-9 klasiv. Kyiv, $2008,112$.

10. Yushkevich, T. P., Romanov, I. V. (2017). Primenenie elementov krossfita v trenirovochnom processe desyatiborcev 15-16 let. Mir sporta, 1(66), 17-23.

Стаття надійшла до редакції 23.10.2019 p. 